\title{
Festival de Cannes 2008
}

\author{
By Ron Holloway
}

Fall 2008 Issue of KINEMA

ANY WAY YOU LOOK AT IT, 2008 was a watershed year at the Cannes film festival. Looking ahead, this was Thierry Frémaux's first year as délégué général, the first time he was listed in the catalogue as the man who put his own signature on the selection. Last year, he was down simply as director artistique, to wit: the festival's artistic director under the friendly aegis of président Gilles Jacob. Looking back, Gilles Jacob is currently penning his collection of memories as the festival icon over the past 30 years. Knowing Jacob's unrestrained love for the Festival de Cannes, a spring event he has personally molded into an institution that stands head and shoulders over all other A-category festivals, his memoirs will surely offer insights into how he was able to balance the ideals of auteur cinema with the public's demand for starlets on the grand staircase and box-office entertainment fare.

This said, Thierry Frémaux found himself uncomfortably on the firing line at the $61^{\text {st }}$ Festival de Cannes (13-24 May 2008), because last year's $60^{\text {th }}$ anniversary festival was rated by critics and professionals alike as a banner year in Cannes history. One that would be hard to beat by any stretch of the imagination. A milestone in Cannes history, some contended. True, a festival is only as good as the production year itself. But in world cinema there are other ways to smooth over the gaps in a lean season - like unveiling previously undiscovered vistas of cinema art that surface readily but need an astute scout to define talent and potential. In this regard, Cannes has the best crew of scouts on record.

So if nothing of interest is found in any given year in traditional filmlands, all Thierry Frémaux has to do is to search other continents for new talent and thematic material. Thus, in the late 1990s tired European cinema gave way to vibrant Asian cinema. And this year, unless my hunch is far off the mark, Asian cinema is being nudged aside by Latin American film waves.

How did Thierry Frémaux's virgin year as festival chief fare? Several contrasting opinions have been offered in the press and media. Like: entries by auteur directors barely scored on the critics' lists in trade publications. Or: films about the mafia and prison life dominated. Further: the documentary film has found a permanent niche in the competition, including a first-time animated documentary. In general, Cannes 61 presented itself as a quite depressing mirror reflection of our present-day chaotic world.

\section{Latino Cinema}

The current strength of Latin American cinema was confirmed on opening night: Brazil's Fernando Meireilles bowed with Blindness (Brazil-Japan-Canada-USA). A claustrophobic futuristic tale set in a prison for an urban population afflicted by a plague that appears to be contagious, the reference to Guantánamo was unmistakable. Based on Portuguese Nobel Prize winning author José Saramago's bestselling allegorical Essay on Blindness, the book is one of those high-water-marks in literature that proved too much for a movie straightjacket by an aspiring auteur reaching for the moon.

It was followed on the next day by Pablo Trapero's impressive but rather heavy-handed Leonera (Lion's Den, Argentina-Brazil-South Korea), a murder caper that finds an innocent pregnant woman sentenced to prison for apparently killing her lover. The compelling element in this rather familiar prison account is that actress Martina Gusman, the film's co-producer, was in fact pregnant, thus adding to the realism of a story that ends some years later with a contrived escape across the border with her infant son.

Two more Latin American entries by name directors drew mixed reactions from critics. Walter Salles and Daniela Thomas's Linha de passe (Passing Line - a soccer expression, Brazil), a four-son family drama set in the teaming slums of Sao Paulo, recalled Visconti's masterful Rocco and His Brothers (Italy, 1960). A wandering episodic drama, it won a Best Actress award for Sandra Corveloni, the long-suffering mother whose trouble-making brood stem partially from being offspring by different fathers.

Also, Lucrecia Martel's La mujer sin cabeza (The Woman Without a Head, Argentina-Spain-France-Italy) came across as a rambling portrait of a middle-aged woman-dentist who loses control of her sensory powers. We are made to believe that the memory loss - or apparent fantasy delusion - was due to a head concussion 
suffered when her car hit an unseen object or person on the highway. Yet after her recovery, we still don't have a clue as to what is really going on in this deranged woman's head.

Steven Soderbergh's Che (USA-Spain-France), a two-part, four-and-a-half-hour epic on the life and times of Che Guevara, stars Benicio Del Toro in role of the legendary revolutionary. The hottest ticket in Cannes, Che chronicles two paths taken by the asthmatic revolutionary who had helped Castro to defeat Batista in Cuba (Part One, 1956-59) and then lost his way in the jungles of Bolivia (Part Two, 1966-67). Del Toro's multi-faceted acting performance merited him the Best Actor award at Cannes. Puzzling, however, was why the reenacted visit of Che to the United Nations in 1964 had been included as a tie-together segment between the historical halves. Was it there to underscore his intellectual acumen, particularly when Cold War journalists tried to bait him with loaded questions and "commie" accusations? Probably.

\section{Auteur Cinema}

Nuri Bilge Ceylan's Ü̧̧ maymun (Three Monkeys, Turkey-France) was one of the frontrunners for Palme d'Or laurels. Programmed early in the festival, his Three Monkeys prompted dozens of interviews with the director and his actress wife, Ebru Ceylan. On the surface, Three Monkeys - referring to the "monkey metaphor" of hear-no-evil, see-no-evil, speak-no-evil - comes across as a tight kammerspiel about human failings. But below the surface it also raises the philosophical question about how excessive lying to cover up the truth can lead to tragic consequences. As strong as the direction is - Ceylan was awarded Best Director at Cannes - what's lacking is his patented aching indictment of human failings that characterized his earlier films: Uzak (Distant, 2003), Grand Jury Prize at 2003 Cannes, and Iklimler (Climates), FIPRESCI Critics Prize at 2006 Cannes. Next time.

Jean-Pierre and Luc Dardenne's Le silence de Lorna (Lorna's Silence, Belgium-France-Italy-Germany) is an engaging film along the lines of their previous Palme d'Or winners: Rosetta (1999) and L'enfant (The Child, 2005). In Lorna's Silence, set in Li ge, an illegal Albanian immigrant - played by talented Kosovo actress Arta Dobroshi, who learned French to get the part - falls into the hands of a slick taxi-driver with mafia contacts in order to obtain Belgian citizenship. The marriage scheme begins with her marriage to a junkie, who is expected to die of an overdose, so that Lorna can then marry a Russian mafia boss to enable the latter to obtain Belgian citizenship. But when her own unexpected pregnancy tips the apple-cart, and Lorna finds herself without a passport, the game becomes dangerous. The film ends on a note of hope when Lorna escapes from mafia captors into the forest. For Lorna's Silence the Dardenne Brothers were awarded Best Screenplay.

Arnaud Desplechin may be one of the darlings of the new nouvelle vague (this is the fourth time he has competed for Palme d'Or laurels), but his Un conte de Noël (A Christmas Tale, France) has the ear markings of a vehicle for the home audience. The giveaway is the footnote "Roubaix" found in the preproduction title - like the Dardenne brothers' Li ge, this is where the director was born and raised. The setting of this twoand-a-half-hour, talking-head family drama is an estate in Roubaix, where a painful reunion takes place at Christmas that sparks animosity stemming from a family tragedy that had happened years before. Catherine Deneuve, as the ailing matriarch who needs a bone marrow transplant from one of her difficult offspring, was awarded the Special $60^{\text {th }}$ Anniversary Prize at Cannes.

Kornel Mundruczo's Delta was also favoured for Cannes laurels, if only because his debut feature, Szep napok (Pleasant Days, 2002), a grim look at small town mores, had won him a six-month stay for young filmmakers at the Cannes Residence Program in Paris. Moving up the Cannes ladder, his Johanna, presented in the Un Certain Regard section at the 2005 Cannes, drew high critical praise as a rare example of a film-oratorio. Delta, flooded with striking visual imagery of lush fauna in the Danube delta, was a standout at Cannes. The crippling element was the dilemma Mundruczo faced when his leading actor (Lajos Bertok, to whom the film is dedicated) died in the middle of shooting - to be eventually replaced by a violin virtuoso, Felix Lajko, who also scored the film. Lajko, however, brings a vulnerable innocence to this tragic tale of incest and retribution. Delta was awarded the FIPRESCI Critics Prize.

Atom Egoyan's Adoration (Canada-France) was the Armenian-Canadian director's tenth appearance at Cannes (including a stint as a member of the international jury). The director is always good for a surprise. In Adoration, linked to the chat phenomenon of the Internet age, a high school lad attempts to come to terms with clichéd prejudices of Canadian society. The film apparently echoes Atom's own Toronto high 
school experiences, when, as an adolescent, he immersed himself in film and video technology to explore role-playing at its most fundamental level. This time, internet chatters assume identities online, as the participants, all part of the lad's school project, explore the reasons behind a known terrorist act. Adoration was awarded the Ecumenical Prize.

Queried on his reasons for making The Palermo Shooting, Wim Wenders stated in his press book: "I wanted to tell a story without knowing how it would end, to know my subject and my topics without having to peg them to a story from the beginning." Set in the Sicilian capital, a mythical city of death, The Palermo Shooting is a story about Death in a clinch with a burnt-out photographer. Finn, a high-paid chic-fashion photographer is tired of globe-trotting fashion shoots. One evening on the Autobahn, while shooting wildly with his spin-around camera, Finn accidentally captures an image of Death - Dennis Hopper in a grey hood who is so enraged that he takes off in pursuit - all the way to Palermo. Along the way, Death has been firing spectral arrows at Finn that leave no trace immediately after the painful impact. The mystery is half-solved when Finn meets the beautiful Flavia (Giovanna Mezzogiorno), an art restorer working on a $14^{\text {th }}$ century painting by an unknown Sicilian master. The painting features Death shooting arrows at the depraved in church and state!

\section{Return of the Documentary}

As the Cannes carousel rolled on, a pair of Italian docu-dramas on how the mafia has infiltrated the social fabric, to say nothing of having reached the higher echelons of political circles, won increasing accolades of praise - like the proverbial snowball rolling down a hill. For some critics, this apparent new wave of Italian mafia films heralded a revival of Neorealist cinema.

Programmed towards the middle of the festival, the most talked about film at Cannes was suddenly Matteo Garrone's Gomorrah (Gomorra, Italy), awarded the runner-up Grand Jury Prize. Based on the non-fiction best-seller with the same title by Roberto Saviano, it deals with the inner workings of the Camorra mafia in Naples. According to one unofficial report, the worldwide earnings of the Camorra is estimated at well over $\$ 200$ billion annually, with the income reaching from drugs and extortion to waste disposal and the haute culture fashion market. That alone makes Gomorra interesting, while the intertwining stories feature some bravura acting performances. The story of how a young delivery boy, longing to join the mafia, sets up a woman for execution at the hands of rival toughs is chilling for its authenticity.

By the same token, Paolo Sorrentino's Il Divo (Italy-France), a portrait of former Christian Democrat Prime Minister Giulio Andreotti (brilliantly interpreted by Toni Servillo) is anything but flattering. Rather, Servillo's performance is peppered with such delightful moments of outrageous wit and humour that Andreotti comes across as a real-life, modern-day, double-dealing Machiavellian Prince - one who will stop at nothing to retain power, cost what it may. Il Divo was awarded the Special Jury Prize.

Unfortunately overlooked for a festival award, Ari Folman's animation-documentary Waltz with Bashir (Israel-France-Germany-USA) is the one film in the Cannes competition that you cannot easily forget and this for any number of reasons. The traumatic journey of the filmmaker himself into his own past as a young soldier during the Lebanon Crisis, the story is told in hand-drawn comic-book fashion to capture the viewer's attention and to spotlight confessional reports by eyewitnesses on what really happened in June of 1982, when Israeli forces invaded Lebanon. As though to underscore Israeli complicity in the massacre of hundreds (estimated as high as 3,000) Palestinian civilians by Lebanese Phalangists in the Beirut refugee camps of Sabra and Shatila, soldier-filmmaker Ari Folman shifts away from animation in the final scene to jarring actual documentary footage of the few survivors leaving the camps. As a statement of conscience and shame, guilt and expiation, Waltz with Bashir stands high on the list of the best antiwar films made.

Programmed on the last day of competition, Laurent Cantet's Entre les murs (The Class, France) was unanimously awarded the Palme d'Or. Based on an autobiographical best-seller by François Begaudeau, who plays the lead in this finely sketched story about 13- and 14-year-old students at a multi-cultural school in a tough Parisian neighbourhood, The Class covers one year in a teacher's ordeal to instill a love for learning - along with a tolerance for discipline that makes learning possible in the first place. Throughout an entire school year in preparation for shooting the film, they ran a workshop for volunteer students between the ages of 13 to 16, allowing the kids to improvise their own roles as they went along. In the process, both the students and the three-man camera crew got to know each other, thus enabling a smooth working relationship 
when the final casting was made just days before the actual shooting began. Films like The Class come along only once in a while.

\section{References}

\section{AWARDS \\ Official Competition}

Palme d'Or, Best Film

Entre les murs (The Class, France), dir Laurent Cantet

\section{Grand Prix}

Gomorra (Gomorrah, Italy), dir Matteo Garrone

Prix du Jury / Special Jury Prize

Il Divo (Italy-France), dir Paolo Sorrentino

\section{Best Director}

Nuri Bilge Ceylan, Uç maymun (Three Monkeys, Turkey-France)

Best Actor

Benicio Del Toro, Che (USA-France-Spain), dir Steven Soderbergh

\section{Best Actress}

Sandra Corveloni, Linha de passe (Passing Line, Brazil-France), dir Walter Salles

\section{Best Screenplay}

Jean-Pierre and Luc Dardenne, Le Silence de Lorna (Lorna's Silence, Belgium-France-Italy-Germany), dir Jean-Pierre and Luc Dardenne

\section{Special $60^{\text {th }}$ Anniversary Prize}

Clint Eastwood, director-composer, Changeling (USA)

Catherine Deneuve, actress, Un conte de Noël (A Christmas Tale, France), dir Arnaud Desplechin

Palme d'Or, Best Short Film

Megatron (Romania), dir Marian Crisan

Special Mention

Jerrycan (Australia), dir Julius Avery

Un Certain Regard Prize

Tulpan (Kazakhstan-Russia-Poland-Germany), dir Sergei Dvortsevoy

Jury Prize

Tokyo Sonata (Japan), dir Kiyoshi Kurosawa

\section{KnockOut Prize}

Tyson (USA), James Toback

\section{Hope Prize}

Johnny Mad Dog (France-Belgium), dir Jean-Stéphane Sauvaire

Prix Coup de Cour

Wolke 9 (Cloud 9, Germany), dir Andreas Dresen

Caméra d'Or, Best First Film

Hunger (Australia), dir Steve McQueen

FIPRESCI (International Film Critics) Awards

Official Competition

Delta (Hungary-Germany), dir Kornel Mundruczo 
Un Certain Regard

Hunger (Australia), dir Steve McQueen

International Critics Week and Directors Fortnight

Eldorado (Belgium-France), dir Bouli Lanners - Directors Fortnight

Ecumenical Jury Prize

Adoration (Canada-France), dir Atom Egoyan

Directors Fortnight

Prix Regards Jeunes / Young Eyes Prize

Eldorado (Belgium-France), dir Bouli Lanners

Label Europa Cinéma Prize (Best European Film)

Eldorado (Belgium-France), dir Bouli Lanners

CICAE Prix Art et Essai

Slepé lásky (Blind Loves, Slovakia), dir Juraj Lehotský

SACD - French Society of Dramatic Authors and Composers

Les bureaux de Dieu (God's Offices, France), dir Claire Simon

"Un Regard Neuf" Short Film Prize

Muro (Brazil), dir Tiao

International Critics Week Grand Prize

Snijeg (Snow, Bosnia-Herzegovia-Germany-France-Iran), dir Aida Begiæ

SACD - French Society of Dramatic Authors and Composers

Best Screenwriter

Jean-Claude Van Rijckeghem et Pat Van Beirs, Aanrijding in Moscou (Moscow, Belgium, Belgium), dir Christophe Van Rompaey

\section{ACID/CCAS Support Award}

Aanrijding in Moscou (Moscow, Belgium, Belgium), dir Christophe Van Rompaey

OFAJ/TV5MONDE (VERY) Young Critic Award

La sangre brota (Blood Appears, Argentine-France-Germany), dir Pablo Fendrik

Canal + Grand Prize for Best Short Film

Next Floor (Canada), dir Denis Villeneuve

Kodak Discovery Award for Best Short Film

Skhizein (France), dir Jérémy Clapin

Regards Jeunes Prizes

Eldorado (Belgium-France), dir Bouli Lanners - Directors Fortnight

Vse umrut a ja ostqanus (Everybody Dies Except Me, Russia), dir Valeria Ga Guermanika - International Critics Week.

Prix de la Jeunesse (Youth Prize)

Tulpan (Kazakhstan-Russia-Poland-Germany), dir Sergei Dvortsevoy - Un Certain Regard

Prix Radio France-Culture for Career Achievement

Sandrine Bonnaire, actress-director

\section{La Cinéfondation Awards}

First Prize

Anthem (Israel), dir Elad Keidan

Second Prize

Forbach (France), dir Claire Burger, France 
Third Prize (ex aequo)

Stop (South Korea), dir Park Jae-ok

Roadmarkers (Finland), dir Juho Kuosmanen

\section{Author Information}

Ron HOLLOWAY (1933-2009) was an American critic, film historian, filmmaker and correspondent who adopted Europe as his home in the early fifties and spent much of his life in Berlin. He was an expert on the study of German cinema and against all odds produced, with his wife Dorothea, the journal German Film, keeping us up-to-date with the work of directors, producers and writers and the showing of German films around the world.

In 2007, Ron Holloway and his wife were awarded the Berlinale Camera Award. Ron also received the Bundesverdienstkreuz (German Cross of Merit), Polish Rings, Cannes Gold Medaille, the American Cinema Foundation Award, the Diploma for Support of Russian Cinema and an honorary award from the German Film Critics' Association.

Ron was also a valued contributor to Kinema for the past fifteen years. 